\title{
A clinical study of postdated pregnancy
}

\section{Shilpa Nitin Chaudhari ${ }^{1 *}$, Devika B. Bhikane ${ }^{2}$, Priyanka Gupta ${ }^{3}$}

\begin{abstract}
${ }^{1}$ Department of Obstetrics and Gynaecology, Shrimati Kashibai Navale Medical College and General Hospital, Narhe, Pune, Maharashtra, India

${ }^{2}$ Department of Obstetrics and Gynaecology, Cloud Nine Hospital, Pune, Maharashtra, India

${ }^{3}$ Department of Obstetrics and Gynaecology, Dr. D.Y. Patil Medical College and Research Center, Pimpri, Pune, Maharashtra, India
\end{abstract}

Received: 16 February 2017

Revised: 20 February 2017

Accepted: 24 March 2017

\author{
*Correspondence: \\ Dr. Shilpa Nitin Chaudhari, \\ E-mail: drshilpachaudhari@yahoo.com
}

Copyright: () the author(s), publisher and licensee Medip Academy. This is an open-access article distributed under the terms of the Creative Commons Attribution Non-Commercial License, which permits unrestricted non-commercial use, distribution, and reproduction in any medium, provided the original work is properly cited.

\section{ABSTRACT}

Background: Objective of the study was to find out the incidence of maternal complications, perinatal mortality and morbidity in postdated pregnancies. Design of the study was prospective observational study.

Methods: Patients who have completed 40 weeks of gestational age, patients who were sure of the date of last menstrual period (LMP) along with 1st trimester obstetrics scan were included. Patients not sure of LMP were excluded.

Results: There is high fetal and maternal risk associated with postdated pregnancy. Total 100 cases were selected from antenatal clinic and Labour Room and were divided into two groups. Study group and control group, 50 cases in each. Induction rate is more in postdated pregnancies. Incidence of operative deliveries is 54\% in study group. Postpartum haemorrhage and septicaemia are the most common maternal complication in the study group. Perinatal mortality is higher and more NICU admissions were required.

Conclusions: Considering this, policy of early intervention should be undertaken in postdated pregnancy to avoid maternal and perinatal complications.

Keywords: Maternal complications, Post datism, Perinatal morbidity

\section{INTRODUCTION}

Post dated pregnancy is defined as one which has crossed expected date of delivery. Pregnancy more than 42 weeks or more than 294 days is called post term pregnancy. Fernandos Arias defined prolonged pregnancy as those pregnancies advancing beyond the expected date of delivery (EDD). ${ }^{1}$

Prolongation of pregnancy complicates up to $10 \%$ of all pregnancies and carries increased risk to mother and fetus. ${ }^{2,3}$
Post term perinatal mortality is greater than that of term pregnancy in almost all studies reviewed. ${ }^{4}$ The growth and survival of most post dated infants suggests that the placenta uncommonly deteriorates with increasing length of gestation; thus the changes seen in fetuses afflicted with post maturity syndrome may not be explained by placental findings alone. Vorherr described critical reductions of fetal oxygen supply after $43^{\text {rd }}$ week of gestation by cord blood oxygen content determinations. ${ }^{4}$

The combination of continued fetal growth and arrested placental growth may lead to situation of decreasing placental nutrient reserve, compromised fetal circulation and eventually fetal distress. However, a recent electron 
microscopy study of placental changes in prolonged pregnancy suggests that the uteroplacental ischemia and not placental aging may be more important in genesis of post maturity syndrome. ${ }^{5}$

Prolonged pregnancies are associated with an increased incidence of macrosomia. Macrosomia infants account for about $1 \%$ of term deliveries and $3-10 \%$ of post term deliveries. ${ }^{6}$ Post maturity infants particularly with macrosomia and post maturity are at increased risk of hypoglycemia. They also have increased chance of polycythemia. $^{7}$

The maternal risks of postdated pregnancy are often underappreciated. These include an increase in labor dystocia $(9-12 \%$ vs $2-7 \%$ at term), an increase in severe perineal injury $\left(3^{\text {rd }}\right.$ and $4^{\text {th }}$ degree perineal lacerations) related to macrosomia $(3.3 \%$ vs $2.6 \%$ at term) and operative vaginal delivery, and a doubling in the rate of cesarean delivery ( $14 \%$ vs $7 \%$ at term)..$^{8-11}$ The latter is associated with higher risks of complications such as endometritis, hemorrhage, and thromboembolic disease..$^{10,12}$

As there is fetal and maternal risk associated with post dated pregnancy, need of induction is more with postdated pregnancy. There is general consideration that perinatal mortality and morbidity controversy is centered on adequacy of detecting different methods for the fetus at risk, the time when testing should be done, the method of monitoring, optimum time for delivery and mode of delivery. The availability of biophysical profile and electronic fetal monitoring can affect the outcome of a given pregnancy.

One recent systematic review showed that a policy of labor induction for women with postdated pregnancy compared with expectant management is associated with fewer perinatal deaths and fewer Caesarean sections. ${ }^{13}$

With this background present study was undertaken to find out incidence of postdated pregnancies, associated maternal complications and perinatal morbidity and mortality.

\section{Objective of the study}

- To study the incidence of postdatism and maternal complications in postdated pregnancies.

- To study the perinatal mortality and morbidity in postdated pregnancies.

\section{METHODS}

The study was conducted in the Department of Obstetrics and Gynecology, of PG and UG teaching tertiary care centre of Maharashtra for a period of 2 years. 100 cases were selected from antenatal clinic and Labor Room. They were divided into two groups, 50 cases each in Study group and control group.

\section{Inclusion criteria}

Patients who have completed 40 weeks of gestational age and who were sure of the date of last menstrual period (LMP) along with $1^{\text {st }}$ trimester obstetrics scan were included. Patients not sure of LMP were excluded.

The postdated patients were divided into two groups.

Group weeks of gestation:

- Control 37-40

- Study $>40$

Complete clinical assessment of postdated patients was done including associated maternal conditions and complications. Fetal monitoring was done with the help of nonstress test, ultrasonography and daily fetal movement count. With the help of above monitoring timely interventions were done.

Labor was monitored closely. All the patients in study and control groups were monitored throughout the labor and the incidence of intrapartum fetal asphyxia was noted.

The new born was examined after birth for evidence of asphyxia, meconium aspiration and other neonatal complications. Birth weight was recorded. The neonatal outcome was correlated with degree of postdatism and it was compared with control.

The study was approved by ethical committee. Consent of all the patients in the study group was taken and proper Performa was formulated and filled for all the patients. Parametric test was applied to evaluate the significance of the study.

\section{RESULTS}

Comparative study of patients in case and control group as per age and parity were not found to be statistically significant.

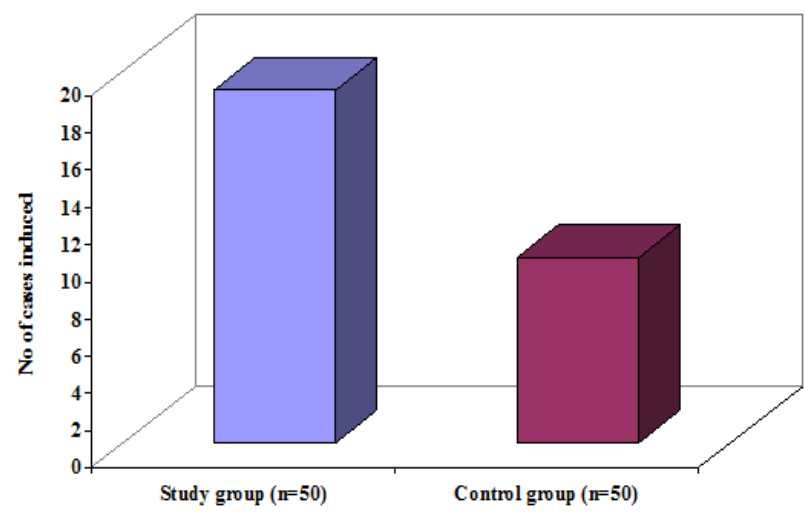

Figure 1: Induction rate wise distribution of cases in study and control group. 
Figure 1 shows induction rate wise distribution of cases in study group. 19(38\%) cases in study group required induction as compared with $10(20 \%)$ cases in control group. This mean number was analyzed quantitatively within group. The $\mathrm{p}$ value is $<0.05$ which is statistically significant.

Table 1: Comparison of associated factors in study and control groups.

\begin{tabular}{|c|c|c|c|c|}
\hline $\begin{array}{l}\text { Associated } \\
\text { factors }\end{array}$ & $\begin{array}{l}\text { Study } \\
\text { group } \\
(\mathbf{n}=50)\end{array}$ & $\begin{array}{l}\text { Control } \\
\text { group } \\
(n=50)\end{array}$ & $\begin{array}{l}\mathbf{Z} \\
\text { value }\end{array}$ & $\begin{array}{l}\mathbf{P} \\
\text { value }\end{array}$ \\
\hline $\begin{array}{l}\text { Previous } \\
\text { LSCS }\end{array}$ & $\begin{array}{l}5 \\
(10 \%)\end{array}$ & $8(16 \%)$ & 0.89 & $>0.05$ \\
\hline preeclampsia & $1(2 \%)$ & $2(4 \%)$ & 0.59 & $>0.05$ \\
\hline $\begin{array}{l}\text { Severe } \\
\text { oligohydram } \\
\text { nios }\end{array}$ & $4(8 \%)$ & $9(18 \%)$ & 1.50 & $>0.05$ \\
\hline IUGR & $1(2 \%)$ & $2(4 \%)$ & 0.59 & $>0.05$ \\
\hline CPD & $2(4 \%)$ & $2(4 \%)$ & 0 & $>0.05$ \\
\hline GDM & $1(2 \%)$ & $1(2 \%)$ & 0 & $>0.05$ \\
\hline
\end{tabular}

Table 1 shows comparison of associated factors both in study and control group. findings were not statistically significant.

Table 2: Comparison of indications of cesarean section in study and control group.

\begin{tabular}{|lll|ll|}
\hline Indication & $\begin{array}{l}\text { Study } \\
\text { group } \\
(\mathbf{n = 5 0}\end{array}$ & $\begin{array}{l}\text { Control } \\
\text { group } \\
(\mathrm{n}=50)\end{array}$ & $\begin{array}{l}\mathrm{Z} \\
\text { value }\end{array}$ & $\begin{array}{l}\mathrm{P} \\
\text { value }\end{array}$ \\
\hline Fetal Distress & $\begin{array}{l}14 \\
(28 \%)\end{array}$ & $7(14 \%)$ & 1.74 & $>0.05$ \\
\hline Absent Liquor & $1(2 \%)$ & 0 & 1.01 & $>0.05$ \\
\hline CPD & $4(8 \%)$ & $2(4 \%)$ & 0.85 & $>0.05$ \\
\hline $\begin{array}{l}\text { NPOL (non } \\
\text { progress of }\end{array}$ & $2(4 \%)$ & $1(2 \%)$ & 0.59 & $>0.05$ \\
labor) & $1(2 \%)$ & 0 & 1.01 & $>0.05$ \\
\hline $\begin{array}{l}\text { Persistent } \\
\text { occipito } \\
\text { posterior }\end{array}$ & $5(10 \%)$ & $8(16 \%)$ & 0.89 & $>0.05$ \\
\hline $\begin{array}{l}\text { Previous LSCS } \\
\text { PROM }\end{array}$ & 0 & $1(2 \%)$ & 1.01 & $>0.05$ \\
\hline $\begin{array}{l}\text { Severe } \\
\text { Oligohydramnios }\end{array}$ & $3(6 \%)$ & $1(2 \%)$ & 1.03 & $>0.05$ \\
\hline Thick Meconium & $1(2 \%)$ & $1(2 \%)$ & 0 & $>0.05$ \\
\hline
\end{tabular}

Table 2 shows indication for caesarean section wise distribution. Commonest indication was fetal distress in study group which contributed for $28 \%$ compare to control group it was $14 \%$. Total $27 \%$ ceserian sections were done in study group. Some of them had more than one indication (like severe oligohyramnios with fetal distress) so no. of indications is not matching in above table. The $\mathrm{p}$ value is statistically not significant. ( $p>0.05)$.
Table 3: Maternal complication wise distribution of cases in study and control group.

\begin{tabular}{|llll} 
Complication & $\begin{array}{l}\text { Study } \\
\text { group }(\mathrm{n}=50)\end{array}$ & $\begin{array}{l}\text { Control } \\
\text { group }(\mathrm{n}=50)\end{array}$ & $\mathrm{P}$ \\
Value \\
\hline PPH & $4(8)$ & $2(4)$ & $>0.05$ \\
\hline Septicemia & $1(2)$ & 0 & $>0.05$ \\
\hline
\end{tabular}

Table 3 shows maternal complication wise distribution of cases in study group. 6 cases had PPH with 4 cases in study group and 2 cases in control group. 1 cases in study group had septicemia. This mean number was analyzed quantitatively within group. The $\mathrm{p}$ value is statistically not significant $(\mathrm{p}>0.05)$.

Table 4: Perinatal outcome in accordance with NICU requirement distribution of cases in study and control group.

\begin{tabular}{|c|c|c|c|}
\hline $\begin{array}{l}\text { Perinatal } \\
\text { outcome }\end{array}$ & $\begin{array}{l}\text { Study } \\
\text { group }(n=50)\end{array}$ & $\begin{array}{l}\text { Control } \\
\text { group }(n=50)\end{array}$ & $\begin{array}{l}\text { P } \\
\text { Value }\end{array}$ \\
\hline IUD & 1 & 0 & $>0.05$ \\
\hline $\begin{array}{l}\text { NICU } \\
\text { admission }\end{array}$ & 17 & 13 & $<0.001$ \\
\hline $\begin{array}{l}\text { Good-Not } \\
\text { required } \\
\text { NICU }\end{array}$ & 32 & 37 & $>0.05$ \\
\hline Total & 50 & 50 & \\
\hline
\end{tabular}

The above table shows perinatal outcome wise distribution of cases in study group. The $\mathrm{p}$ value is statistically significant for NICU admission $(\mathrm{p}<0.001)$.

Table 5: Details of perinatal outcome wise distribution of cases in study and control group.

\begin{tabular}{|c|c|c|c|}
\hline $\begin{array}{l}\text { Perinatal } \\
\text { outcome }\end{array}$ & $\begin{array}{l}\text { Study } \\
\text { group }(\mathbf{n}=50)\end{array}$ & $\begin{array}{l}\text { Control } \\
\text { group }(n=50)\end{array}$ & $\begin{array}{l}\mathbf{P} \\
\text { Value }\end{array}$ \\
\hline IUD & $1(2)$ & 0 & $>0.05$ \\
\hline $\begin{array}{l}\text { NICU } \\
\text { admission } \\
\text { for TTN }\end{array}$ & $11(22)$ & 0 & $<0.001$ \\
\hline $\begin{array}{l}\text { NICU } \\
\text { admission } \\
\text { for birth } \\
\text { asphyxia }\end{array}$ & $6(12)$ & $11(22)$ & $>0.05$ \\
\hline $\begin{array}{l}\text { NICU } \\
\text { admission } \\
\text { for LBW }\end{array}$ & 0 & $1(2)$ & $>0.05$ \\
\hline $\begin{array}{l}\text { NICU } \\
\text { admission } \\
\text { for RDS }\end{array}$ & 0 & $2(4)$ & $>0.05$ \\
\hline Good & $32(64)$ & 37 (74) & $>0.05$ \\
\hline
\end{tabular}

The above table shows indication for details of perinatal outcome wise distribution of 100 cases in study group. The $\mathrm{p}$ values are statistically significant for NICU admission for transient tachypnea of newborn $(\mathrm{p}<0.001)$. 


\section{DISCUSSION}

The present study was conducted to find out the incidence of maternal complications, perinatal mortality and morbidity in postdated pregnancies. Total cases were 100 which were enrolled based on inclusion and exclusion criteria.

Incidence of post dated pregnancies was more in age group 21 to 25 yrs followed by 26 to $30 y r s$ in study group. Majority of postdated pregnancy were seen in age group of 25 to 29 yrs in this study. Beischer in his study found that majority of postdated patients belonged to the age group of 25-30 years, while Bancroft et al found that majority of patients belonged to 21-30 years. ${ }^{14,15}$ Reddy UM et al found in their study that women who are of advance maternal age are at higher risk of still birth through out gestation, the peak risk period is 37 to 41 weeks. ${ }^{16}$

Mode of delivery was not significantly associated with post dated pregnancy compared with term pregnancy. Similar finding was also observed in a study conducted by Katz et al who tested non-aggressive approach to the management of post-date pregnancies involving 156 patients who had reached 294 days of amenorrhea and had a Bishops score of 4 or less. ${ }^{17}$ The numbers of caesarean sections were more in postdated pregnancy compared with normal term pregnancy and it was statistically significant in their study. In our study same finding was observed but the difference was statistically not significant. Similar finding was also observed in a study conducted by Luckas et al which compared outcomes of spontaneous labor in uncomplicated term and post date pregnancy. Cesarean section was significantly more common in women with post dated pregnancy. ${ }^{18}$

So induction rate is higher in study group and is statically significant. Also among indication of induction of labor postdatism along with borderline pelvis in study group is statically significant. Significantly more number of cases in postdated pregnancy required induction compared to term pregnancy.

The incidence of induction quoted by various authors ranged between $20-40 \%$. Present study- $38 \%$. Our results are matching with Shime and Schneider studies. ${ }^{19,20}$

Similar finding was also observed in a study conducted by Crowley $\mathrm{P}$ assessed the effects of interventions aimed at either reducing the incidence or improving the outcome of post date pregnancy. ${ }^{21}$ Routine induction of labor reduced perinatal mortality. This benefit is due to the effect of induction of labor after 41 weeks. Routine induction of labor had no effect on caesarean section. Wennerholm UB compared perinatal and maternal outcomes between elective induction of labor versus expectant management of pregnancies at 41 weeks and beyond. ${ }^{22}$ Elective induction of labor was not associated with lower risk of perinatal mortality compared to expectant management.
Elective induction was associated with a significantly lower rate of meconium aspiration syndrome. More women randomized to expectant management were delivered by cesarean section. The incidence of caesarean section reported by various authors range between 26 to $45 \%$. According to study done by Schneide $36 \%$, Vaidya$28 \%$ Thakur $42.3 \% .^{20,23,24}$ In Present study $36 \%$ was found in control and $54 \%$ in study group. The $\mathrm{p}$ value is statistically not significant. ( $p>0.05)$. Induction of labor was associated with a reduction in the incidence of normal vaginal delivery and an increased incidence of operative vaginal delivery as studied by Parry D. ${ }^{25}$

The incidence of fetal distress as an indication for caesarean section by various authors are as follows: Martin $31.6 \%$, Thakur $10.12 \%$. In Present study- $21 \% .^{24,26}$ None of the indication for caesarean section was statistically significant in study group and control group.

Postpartum hemorrhage and septicemia were maternal complication in study subjects. Out of 100 cases 45 cases were delivered by LSCS out of these 45 cases $27(54 \%)$ were in study group and $18(36 \%)$ were in control group. Caesarean rate was higher in study group compared to control but not significant statistically. None of the factor was significant among postdated pregnancy compared with term pregnancy. According to study done by Aaron, estimated rates of maternal complications increase beyond 40 weeks of gestation. Beyond that the rates of operative vaginal delivery, $3^{\text {rd }}$ or $4^{\text {th }}$ degree perineal laceration and chorioamnionitis all increases. $(\mathrm{p}<0.001)$, and rates of postpartum hemorrhage, endometritis and primary caesarean delivery increased at 41 weeks of gestation. ${ }^{27}$ It has been traditionally accepted that complications are at their minimum in term pregnancies i.e. from 37-40 weeks. However Fernando Arias found that complications start to increase significantly once pregnancy continues beyond 40 weeks. ${ }^{1}$ The frequency of complications was $5.6 \%$ when pregnancy ended between $37-40$ weeks compared to $20 \%$ when pregnancy remained between 41 weeks.

More number of newborns required Neonatal intensive care unit (NICU) admission among post dated pregnancy compared to term pregnancy in study group. Similar finding was also observed in a study conducted by Luckas $M$ compared outcomes of spontaneous labor in uncomplicated term and postdate pregnancy. ${ }^{18}$ The main outcome measures were caesarean section and admission to the NICU. The increase was equally distributed between caesarean sections performed for failure to progress in labor and fetal distress. Uncomplicated post-term pregnancy is associated with increased rates of obstetric and neonatal interventions in terms of caesarean section and NICU admissions.

Transient tachypnea of newborn was common factor requiring NICU admission among the postdated pregnancy compared to control group with term pregnancy. There is well recognized increased risk of fetal and maternal morbidity and mortality in pregnancies that extend into 
postdated period. Routine dating of pregnancy using early USG reduces the rate of prolonged pregnancy. Induction of labor at 41 weeks gestation appears to be an effective strategy to reduce the risk of fetal and maternal morbidity and mortality. It appears that smaller term fetuses run a greater risk than their larger counterparts although current method of antepartum assessment of fetus are still inadequate. So currently the only policy of benefit is routine induction of labor after 40 weeks, confirming fetal maturity.

Postdatism with other complications will be a very high risk pregnancy in terms of perinatal and maternal outcome, policy of early intervention should be undertaken.

\section{CONCLUSION}

Postdated pregnancy is not related with age and parity. Common factors associated postdated pregnancies is severe oligohydroamnios. Count to 10 i.e. Daily fetal movement count (DFMC) method is important alternative to use of electronic fetal monitoring. Induction rate is more in postdated pregnancies. Meconium in the amniotic fluid is found in $12 \%$ cases in study group. Incidence of operative incidence is more when oligohydramnios and postdated pregnancy present together i.e. $16 \%$ in study group and $10 \%$ in control group. Incidence of operative deliveries in postdated group is significantly high. Most common indication of cesarean section was fetal distress (28\%). Post partum hemorrhage (PPH) occurred in $8 \%$ of patients and septicemia in $2 \%$ of patients, in study group. Average birth weight observed was in range of 3 to $3.5 \mathrm{~kg}$ (46\%) in study group compared to (24\%) in control, which was statistically significant. Incidence of fetal distress was $14 \%$ in control group and $28 \%$ in study group. Perinatal death was seen in $2 \%$ due to birth asphyxia in case group and nil in control group. More number of newborns required NICU admission among post dated pregnancy. Transient tachypnea of newborn was common reason requiring NICU admission among the post dated pregnancy.

Uncomplicated post-term pregnancy is associated with increased rates of obstetric and neonatal interventions in terms of cesarean section and NICU admissions.

In conclusion one should consider postdated pregnancy as a high risk condition. Considering the above-mentioned reasons of perinatal outcome, most of the patients will be benefited from more aggressive induction of labor after 41 weeks or primary cesarean section in presence of obstetric indication.

The most appropriate direction appears to be a policy of induction of labor after 41 weeks, after assessing the fetal maturity and with evidence of ripened cervix or when fetal compromise is documented so that the incidence of maternal and perinatal mortality and perinatal morbidity can be brought down to acceptable and comparable figures.
Funding: No funding sources

Conflict of interest: None declared

Ethical approval: The study was approved by the Institutional Ethics Committee

\section{REFERENCES}

1. Fernando Arias. Practical guide to high risk pregnancy and delivery 3 Edition; India Harcourt private limited; 2008:255-270.

2. Olesen AW, Westergaard JG, Olsen J. Perinatal and maternal complications related to post term delivery: a national register-based study, Am. J Obstet Gynecol. 1978-1993;189:222-227.

3. Norwitz ER, Snegovskikh VV, Caughey AB Prolonged pregnancy: when should we intervene? Clin Obstet Gynecol. 2007;50:547-57.

4. Vorherr H. Placental insuffiency in relation to postterm pregnancy and fetal postmaturity: Evaluation of fetoplacental function Management of post term gravida. Am J Obstet Gynecol. 1975;123:67.

5. Jones JP, Fox H. Ultrastructure of the placenta in prolonged pregnancy. J Pathol. 1978;126(3):173-9.

6. Spellacy WN, Miller S, Winegar A, Peterson PQ. Macrosomia maternal characteristics and infant complications. 1985;66(2):158-61.

7. Ratnam SS, Arulkumaran S. Post term infant. Obstetrics and Gynecology, $2^{\text {nd }}$ Edition, India Orient Longman. 2003;2:48-53.

8. Rand L, Robinson JN, Economy KE. Post-term induction of labor revisited. Obstet Gynecol. 2000;96(5 Pt 1):779-83.

9. Campbell MK, Ostbye T, Irgens LM. Post-term birth: risk factors and outcomes in a 10-year cohort of Norwegian births. J Obstet. Gynecol. 1997;89(4):5438.

10. Alexander JM, McIntire DD, Leveno KJ. Forty weeks and beyond: pregnancy outcomes by week of gestation. Obstet Gynecol. 2000;96(2):291-4.

11. Treger M, Hallak M, Silberstein T. Post-term pregnancy: should induction of labor be considered before 42 weeks? J Maternal Fetal Neonatal Med. 2002;11(1):50-3.

12. Eden RD, Seifert LS, Winegar A. Perinatal characteristics of uncomplicated postdate pregnancies. Obstet. Gynecol. 1987;69:296-9.

13. Gulmezoglu AM, Crowther CA, Middleton P, et al; Induction of labour for improving birth outcomes for women at or beyond term. Cochrane Database Syst Rev. 2012;6:CD004945.

14. Beischer NA, Evans JH, Townsend L. Studies in prolonged pregnancy. I: Incidence of prolonged pregnancy. Am J Obstet Gynecol. 1969;103:476.

15. Bancroft-Livingston G, Neill DW. Studies in prolonged pregnancy, Cord blood oxygen levels at delivery. J Obstet Gynaecol.1957;64:498-503.

16. Reddy UM, KO CW, Willinger M. Maternal age and risk of stillbirth throughout pregnancy in the United states. Am J Obstet Gynecol. 2006;195(3):764-70. 
17. Katz Z, Yemini M, Lancet M, Mogilner BM, Ben-Hur $\mathrm{H}$, Caspi B. Non-aggressive management of post-date pregnancies. Eur J Obstet Gynecol Reprod Biol. 1983;15:71-9.

18. Luckas M, Buckett W, Alfirevic Z. Comparison of outcomes in uncomplicated term and post-term pregnancy following spontaneous labor. J Perinat Med. 1998;26:475.

19. Jerry S, Douglas JG, Andrews J. Management of prolonged pregnancy. Am. J. Obstet. Gynecol. 1984:148:547.

20. Schneider JM, Olson RW, Curet LB. Amniotic fluid volume as predictor of foetal distress in postdated pregnancy. Am. J. Obstet. Gynecol. 1978;131:473.

21. Crowley P. Interventions for preventing or improving the outcome of delivery at or beyond term. Cochrane Database Syst Rev. 2006;(4):CD000170.

22. Wennerholm UB, Hagberg H, Brorsson B, Bergh C. Induction of labor versus expectant management for post-date pregnancy: is there sufficient evidence for a change in clinical practice? Acta Obstet Gynecol Scand. 2009;88:6-17.

23. Vaidya PR. Post date pregnancy and it's perinatal charectristics J. Obstet. Gynecol. India 1985;35:670.

24. Thakur R, Kelkar YV, Shrivastava N. Perinatal risks in postdated pregnancy resented in 29th all India congre3ss. Obstet. Gynecol; 1985.

25. Parry E, Parry D, Pattison N. Induction of labour for post term pregnancy: an observational study. Aust N Z J Obstet Gynaecol. 1998;38:275.

26. Martinb C, De Paula. Marque AM, Silva D. J. Obstet. Gynecol. 1969;56:830.

27. Caughey AB, Stotland NE. Washington AE, Escobar GJ. Maternal Complications of Pregnancy Increase Beyond 40 Weeks' Gestation. Am J Obstet Gynecol. 2007;1969:155.

Cite this article as: Chaudhari SN, Bhikane DB,

Gupta P. A clinical study of postdated pregnancy. Int J Reprod Contracept Obstet Gynecol 2017;6:207782. 